Rafał Zgorzelski

\title{
Złamani i niezłomni. Losy konfederatów barskich po klęsce
}

Upadek Rzeczypospolitej szlacheckiej poprzedziła klęska rozbiorów będąca konsekwencją niekorzystnej dla państwa sytuacji politycznej na arenie międzynarodowej oraz zapaścią moralną kraju i rozkładem wewnętrznych urządzeń ustrojowych.

Zapoczątkowane przez króla Stanisława Augusta oraz jego otoczenie reformy zmierzały do zmodernizowania państwa i przekształcenia go w nowoczesną "demokrację szlachecką". Utworzenie w 1764 roku Komisji Wojskowej dla Korony, a następnie dla Wielkiego Księstwa Litewskiego stworzyło perspektywy przeprowadzenia niezbędnych reform w wojsku Rzeczypospolitej, które dawno już przestało spełniać rolę zorganizowanej struktury realizują̧cej zadania polityczne państwa ${ }^{\mathrm{I}}$.

Jednakże Stanisław August zmuszony był borykać się, z jednej strony, ze wzrastającą ingerencją w sprawy kraju mocarstw ościennych, które bynajmniej nie były zainteresowane „naprawą Rzeczypospolitej”, a z drugiej strony zmagał się ze wzrastającą opozycją wewnętrzną. Wśród oponentów obozu królewskiego odnajdujemy agentów sąsiednich dworów ${ }^{2}$ oraz wichrzycieli reprezentujących interesy własne i wąskich koterii dworskich, jak również bardziej zorganizowaną opozycję z odmienną wizją reformowania oraz funkcjonowania państwa.

${ }^{1}$ Komisja Wojskowa wyznaczyła dowódców partii kawalerii narodowej (wojsko koronne podzielono na cztery partie: ukraińską, podolską, wielkopolską i małopolską), wyegzekwowała od magnatów zwrot części zawłaszczonych przez nich armat i prochu, ustaliła stan kadry oficerskiej i podoficerskiej. Komisja ograniczyła też proceder sprzedaży szarż wojskowych, wypracowała plan polepszenia sytuacji materialnej żołnierzy, doprowadziła do podwyższenia przez Sejm wydatków na armię, zwiększenia żołdu, utworzenia funduszu dla inwalidów etc.; por. B. Pawłowski, Od konfederacji barskiej do powstania styczniowego. Studia z historii wojskowości, Warszawa 1962, s. 16-19.

${ }^{2}$ Wybitny znawca czasów stanisławowskich oraz autor monografii poświęconej konfederacji barskiej Wladysław Konopczyński opublikował na jej kartach siekrietnyj raschod ambasadora carskiego w Warszawie Iwana Repnina za rok 1767. Niniejszy dokument ukazuje w pełnym świetle skalę korupcji panującej wśród elity politycznej kraju. W gronie agentów wpływu pobierających pieniądze od carycy Katarzyny II odnajdujemy nazwiska postaci pełniących najważniejsze funkcje publiczne w państwie; por. W. Konopczyński, Konfederacja barska, Warszawa 1991, t. 1, s. 17-18. 
Szczególną rolę wśród antykrólewskiej opozycji odgrywa stronnictwo prosaskie sympatyzujące $z$ koncepcją umieszczenia Wettinów na polskim tronie, nastawione zdecydowanie negatywnie do ugrupowania prorosyjskiego, utożsamianego z królem i „familią" Czartoryskich. Wśród ogółu szlachty wzrasta niechęć do carskiego ambasadora Iwana Repnina ingerującego coraz bardziej brutalnie w sprawy suwerennego przecież państwa, co uwidoczniło porwanie i wywiezienie w głąb Rosji, w nocy z 13 na 14 października 1767 roku, głowy opozycji, biskupa krakowskiego Kajetana Soltyka, hetmana polnego koronnego Waclawa Rzewuskiego i jego syna Seweryna oraz biskupa kijowskiego Józefa Jędrzeja Załuskiego ${ }^{3}$.

Niniejsze wydarzenie wstrząsnęło opinią publiczną w kraju i przyspieszylo wybuch zbrojny, zapoczątkowany zawiązaniem 29 lutego 1768 roku w Barze na Podolu konfederacji pod hasłem obrony dawnych praw i wiary. 4 marca 1768 roku powołano związek wojskowy mający na celu usuniecie wojsk rosyjskich $z$ terytorium Rzeczypospolitej oraz objęcie władzy nad całym wojskiem ${ }^{4}$.

$\mathrm{Na}$ temat dziejów politycznych konfederacji barskiej istnieje obszerna literatura $^{5}$ oraz zachowało się wiele źródel pamiętnikarskich ${ }^{6}$. Szereg kwestii związanych $z$ niniejszym wydarzeniem w historii Polski wymaga jeszcze bardziej do-

${ }^{3}$ Ibidem, s. 32-33.

${ }^{4}$ E. Rostworowski, $Z$ dziejów genezy konfederacji barskiej. Zwiqzek wojskowy Pulaskiego a dworski projekt reformy kawalerii, [w:] $Z$ dziejów wojny i polityki. Ksiega pamiątkowa ku uczczeniu siedemdziesiątej rocznicy urodzin Janusza Wolińskiego, red. K. Hanulak, Warszawa 1964, s. 148.

${ }^{5}$ Obok wspomnianej już dwutomowej monografii W. Konopczyńskiego wymienię tu chociażby prace i wypisy źródłowe opublikowane przez tegoz autora: Kiedy nami rządzily kobiety, Londyn 1960; Kazimnierz Pulaski. Życiorys, Kraków 1931; Materialy do dziejów wojny konfederackiej 1768-1774, Kraków 1931, Konfederacja barska. Wybór tekstów, Kraków 1928; T. Korzon, Wewnętrzne. dzieje Polski za Stanislawa Augusta (1764-1794), Kraków-Warszawa 1897, t. 3; J. Krasicka, Kraków i ziemia krakowska wobec konfederacji barskiej, Kraków 1929; A. Kraushar, Losy Miączyńskiego, marszalka konfederacyi barkkiej, generał́a wojsk repubikansskich za czasów wielkiej rewolucji francuzkiej (1769-1793). Obraz historyczny, Petersburg 1902; S. Kwasieborski, Częstochowa za konfederacyi barskiej, Warszawa 1917; K. Pułaski, Z życia księznej kurońskiej. Szkic historyczny, Warszawa 1890; Idem, $Z$ dziejów konfederacji barskiej. Teki Teodora Wessla, podskarbiego wielkiego koronnego (1769-1772), Lwów 1909; H. Sobierajska, Udzial Wielkopolski w konfederacji barskiej, Poznań 1918; Z. Stefanowska, Przemiany tradycji barskiej. Studia, Kraków 1972; W. Szczygielski, Konfederacja barska w Wielkopolsce 1768-1770, Warszawa 1970; Idem, Dzieje ziemi wieluńskiej, Łódź 1969. To jedynie niektóre prace traktujące o dziejach politycznych konfederacji barskiej.

${ }^{6}$ Takie, jak np. T. A. F. de Belcour, Dziennik oficera w siużbie konfederacji barskiej pojmanego przez Maskali, zestanego na Sybir, przekt. Ksawery Godebski, Lwów 1866; K. L. Chojecki, Pamiéć dziel polskich: podróż i niepomysiny sukces Polaków, oprac. W. Turek, Gdańsk 1992; Dziennik zdarzeń w mieście Krakowie w czasie konfederacyi barskiej pisany przez Wojciecha Mączeniskiego, kupca i obywatela krakowskiego, wyd. W. Konopczyński, Kraków 1911, Biblioteka Krakowska, t. 43; J. Kitowicz, Pamiętriki, czyli historia polska, oprac. i wstęp P. Matuszewska, komentarz Z. Lewinówna, Warszawa 1971; P. N. Kreczetnikow, Radom i Bar 1767 i 1768. Dziennik wojennych działań w Polsce korpusem dowodzonego, przeł. K. Podwysocki, [w:] Pamiętniki z XVIII w., Poznań 1874, t. 14; T. Krzyżanowski, Wspomnienia mieszczanina krakowskiego z lat 1768-1807, wyd. W. Prokesch, Kraków 1900, Biblioteka Krakowska, t. 12; J. U. Niemcewicz, Pamiętniki czasów moich, oprac. J. Dihm, Warszawa 1957, t. 1; J. A. Puttkamer, Krótkie zebranie okoliczności, jakimi rozpoczęta, w postępach swoich pomnożona $i$ dotad utrzymana Generalna konfederacja. Sancita, [w:] W. Konopczyński, Polityka i ustrój Generalności konfederacji barskiej. Dwa nieznane przyczynki, Kraków 1928; Pamiętniczek 
glębnej analizy . Szczególnie interesującym zagadnieniem dla badacza wydają się być sylwetki konfederatów barskich oraz dalsze losy poszczególnych Barżan po upadku ruchu ${ }^{8}$.

Podejmując wątek losów konfederatów należy zaznaczyć, że dość znane są w obiegowej literaturze postaci Kazimierza Pułaskiego, czy Józefa Wybickiego'. Pragnąc te zagadnienie rozbudować i zafascynować nim potencjalnych badaczy należałoby prześledzić chociażby w zarysie dzieje uczestników zrywu konfederackiego.

W historiografii dominuje przekonanie, że konfederacja barska była par excellence ruchem szlacheckim. Nie jest to jednak tak oczywiste. Obok przedstawicieli wyższego duchowienistwa (jak biskup kamieniecki Adam Stanisław Krasiński), czy magnaterii (hetman wielki litewski Michał Kazimierz hr. Ogiński) oraz wreszcie średniej i drobnej szlachty (rodziny Pułaskich, Wielhorskich, Miączyńskich, Kitowiczów, Czackich, Kochanowskich, Kossakowskich) uczestniczyły w ruchu żywioly mieszczańskie (Jędrzej Kitowicz) i plebejskie (Sawa Caliński) ${ }^{10}$. Konfederacja barska byla więc ruchem narodowym, a nie stanowym czy kastowym.

Antoniego Hulewicza, konfederaty barskiego, oprac. K. Pułaski, „Niwa” 1886, z. 271, s. 461; Reszty pamiętników Macieja Rogowskiego, rotmistrza konfederacyi barskiej, przed. K. Gaszyński, Paryż 1874; T. z Jablonowskich Sapieżyna, $Z$ pamiętnika konfederatki (1771-1773), wyd. W. Konopczyŕski, Kraków 1914; Archiwum Wybickiego (1768-1801), wyd. A. M. Skałkowski, Gdańsk 1948 t. 1; W. Fiszerowa, Dzieje moje wlasne i osób postronnych. Wiązanka spraw powaznych, ciekawych i błahych, wyd. E. Raczyński, Londyn 1975; Ch. F. Dumouriez, Wojna w Polsce. Z pamiętników generala Dumourieza, [w:] Pamiętniki z XVIII w., Poznan 1865 t. 6; J. Wybicki, Życie moje oraz Wsparnnienie o Andrzeju i Konstancji Zamoyskich, wyd. A. M. Skałkowski, Kraków 1927; Wspomnienia, listy i raporta urzędowe barona de Viomenil, wyslannika rządu francuzkiego do jeneralycyi konfederacji barskiej w latach 1771 i 1772, przetł. S. Prus Jabłonowski, Kraków 1863; [A. L. Zdanowski], Z pamiętnika konfederata barskiego, oprac. K. Pułaski, Przewodnik Naukowy i Literacki, 1896, t. 24. Wymieniam tu tylko bardziej znane w historiografii relacje pamiętnikarskie.

'Na rzetelne opracowanie czeka wciąż omówienie, np. udziału duchowieŕstwa w konfederacji barskiej, biografie poszczególnych przywódców politycznych i dowódców wojkkowych, dzieje konfederacjilokalnych. Ostatnio A. Roćko opublikowała pracę Pamiętniki polskich zesłańców na Syberię w wieku XVIII, Olsztyn 2001, która traktuje równjeż o losach niektórych z konfederatów barskich na Syberii. W ramach seminarium magisterskiego prof. Jerzego Dygdały z Wydzialu Nauk Historycznych Uniwersytetu Mikołaja Kopernika w Toruniu powstaka praca Rafala Zgorzelskiego, Sily zbrojne konfederacji barskiej ( $w$ swietle źródel pamiętnikarskich). Organizacja. Taktyka. Zycie codzienne, Torun 2005.

${ }^{8}$ Jak do tej pory ukazały się wymienione przeze mnie już prace o Kazimierzu Pukaskim i józefe Miączyńskim, a pokrótce scharakteryzowane życiorysy wielu $z$ konfederatów barskich (głównie autorstwa W. Konopczyńskiego, W. Szcrygielskiego, W. Zajewskiego, B. Pawłowskiego i J. Michalskiego) znajdziemy również na łamach wielotomowego wydawnictwa, Polskiego Stownika Biograficznego.

${ }^{9}$ Informacje biograficzne na temat Józefa Wybickiego znajdziemy chociażby w Zyciorysach zastużonych Polaków wieku XVIII i XIX, wyd. A. M. Skałkowski, Poznań 1927 oraz wstępie do Zycie moje (nowe wydanie pamiętnika ukazalo się w 2005 r. nakładem Wydawnictw - Zakład Narodowy im. Ossolińskich i De Agostini Polska). Na temat Kazimierza Pułaskiego ukazało się wiele prac; por. A. Lenkiewicz, Kazimierz Pułaski. Bohaterstwo - zaborczość Moskwy - zdrada narodu, Wroclaw 1994.

${ }^{10}$ Przedstawiciele chłopstwa i mieszczanie angażowali się, zresztą z różnych względów, w konfederację. Ich udzial $w$ ruchu nie byl jednak tak masowy, jak chcieliby tego niektórzy historycy. 
Omawiając dzieje konfederatów barskich po upadku konfederacji „trzeba sobie jasno powiedzieć - jak słusznie zauważył Wojciech Turek - że konfederaci nie byli w ogóle przygotowani psychicznie na klęskę, jaka stała się ich udziałem" ${ }^{\prime \prime}$. Konfederaci barscy byli na ogół przekonani, że ich działania wspiera cała Europa, która nie zostawi Rzeczypospolitej samej sobie $w$ chwili podjęcia walki $z$,imperialną" Rosją. Klęska rozbiorów była dla wielu $z$ nich prawdziwym wstrząsem, a innych utwierdziła w przekonaniu, że jakakolwiek walka zbrojna z Moskalami jest pozbawiona głębszego sensu. Tym należy tłumaczyć to, „dlaczego konfederaci tak masowo usunęli się $w$ cien, $w$ większości zrezygnowali $z$ prowadzenia jakiejkolwiek działalności politycznej i w swej masie nie wykazali się już później czynnym uczestnictwem w epoce sejmu czteroletniego czy powstania kościuszkowskiego ${ }^{x 12}$. Jednakże losy konfederatów nie byly tak jednoznaczne.

U schylku konfederacji na stronę Stanísława Augusta rejterował, składając reces od ruchu barskiego, podskarbi wielki koronny Teodor Wessel, będący wcześniej jednym $z$ najbardziej zaciekłych przeciwników króla ${ }^{13}$. W dniu 23 marca 1772 roku pod Milejowem na stronę króla przeszedł marszałek konfederacji wielkopolskiej i jeden z najznamienitszych dowódców wojskowych Barzan mjr Józef Zaremba ${ }^{14}$. Wielu $\mathrm{z}$ szeregowych uczestników konfederacji oraz pomniejszych dowódców wojskowych i przywódców politycznych złożyło reces od konfederacji i otrzymało od króla odpuszczenie przewin. W zdecydowanej jednak większości przywódcy konfederaccy udali się na emigrację, niektórzy z nich następnie zabiegali, często z powodzeniem, o względy króla i Katarzyny II, a inni pozostali nieugięci w swej postawie.

Z punktu widzenia niniejszej analizy za ważkie wydarzenie należy uznać spotkanie wybitniejszych przywódców konfederackich zainicjowane przez Paca w bawarskim miasteczku Landshut, w którym wzięli udział m.in. Michał Jan Pac i Michał Hieronim Krasiński, a także marszałkowie: ruski Ignacy Potocki, bełski Józef Miączyński, chełmski Józef Wereszczyński, miecznik chełmski i wołyński Konstanty

J. Michalski słusznie polemizuje z W. Szczygielskim, który pragnie widzieć w konfederacji barskiej jedynie ruch "gołoty" szlacheckiej i żywiołu drobnomieszczańskiego; por. J. Michalski, Konfederacja barska w Wielkopolsce 1768-1770 Waclawa Szczygielskiego, Kwartalnik Historyczny, 1971, t. 78 z. 4, s. 956. Wyraźnie przesadzony wydaje się także pogląd W. Majewskiego, który przypisując dużą rolę w konfederacji chtopstwu; por. W. Majewski, Jedrzej Kitowicza a konfederacja barska, Napis. Tom poświęcony literaturze okolicznościowej i użytkowej, Seria VII, Warszawa 2001, s. 325.

"K. L. Chojecki, op.cit., s. 9.

${ }^{12}$ Ibidem, s. 9.

13 Teodor Wessel był jednym z głównych adwersarzy biskupa Adama Stanisława Krasińskiego i pretendentów do przywództwa nad konfederacją. Najpierw głosował 26 marca 1768 roku na posiedzeniu Rady Senatu za wnioskiem o powstrzymanie wymarszu wojsk rosyjskich z kraju i użyciem ich przeciw konfederatom, następnie przystąpił do Baru i usiłował doprowadzic w obozie pod Muszynką do wylonienia "rządu konfederackiego" oraz lansował koncepcję detronizacji Stanisława Augusta, aby wreszcie ponownie znaleźć się w gronie sojuszników króla; por. A. Wasiak, Dzialalność malopolskiego ośrodka konfederackiego w obozie pod Muszynką, Rocznik Sądecki, 1969/1970, t. $10-11$, s. 298.

${ }^{14}$ W. Konopczyński, Dzieje Polski nowożyinej, Warszawa 1999, s. 630. 
Olizar Wołczkiewicz, podkomorzy włodzimierski oraz konsyliarz żmudzki Jacek Antoni Puttkamer. W zjeździe uczestniczyli także Ignacy Bohusz, marszałkowie: chełmiński Michał Zboiński, starosta kowalski, pomorski Michał Lniski, podwojewodzic pomorski, sandomierski gen. mjr. Rafał Tarnowski ${ }^{15}$. Obrady konfederatów trwały od 11 do 14 grudnia 1772 roku. Zwolennikiem ugody $z$ królem byl Michał Wielhorski, poseł konfederatów w Wersalu, a przeciw niej wystąpili zdecydowanie Michał Jan Pac i wojewoda wileński Karol ks. Radziwiłł „Panie Kochanku", którzy najpierw domagali się od Stanisława Augusta uznania konfederacji za legalną, obawiając się pociągnięcia do odpowiedzialności za wszczęcie ruchu' ${ }^{16}$.

Zjazd w Landshut był w zasadzie ostatnim większym spotkaniem przywódców konfederacji barskiej. Następnie każdy z nich prowadził już działania na własną rękę. Jedni, tak jak Pac, pozostali na emigracji, a inni, jak Wielhorski czy Ogiński, pojednali się z królem. Jeszcze w 1774 roku Michał Wielhorski napisał pracę o przywrócenie dawnego rządu, w której starał się, w pewnym sensie, uzasadnić sens zrywu $w$ obronie dawnych praw ${ }^{17}$. W późniejszym okresie propatriotycznie nastawieni przywódcy konfederaccy nie ođegrali już większej roli, nie licząc biskupa Adama Krasińskiego i Józefa Wybickiego.

Zupełnie odrębną grupę stanowią postacie pokroju słowacko-niemieckiego szlachcica węgierskiego Maurycego Augusta Beniowskiego, który najpierw uwięziony na rozkaz stolnika stężyckiego i marszałka konfederacji krakowskiej Michała Czarnockiego, jako podejrzany "dysydent”, znalazł się z kolei w szeregach konfederatów i powędrował na Syberię po tym, jak wpadł w ręce Moskali w kwietniu 1769 roku pod Żydaczowem ${ }^{18}$. Ta malownicza postać weszła na stałe do kanonu literatury światowej i nadal wzbudza zainteresowanie historiografii.

Beniowski, podobnie jak wielu innych konfederatów, został zesłany do Kazania, a później w grudniu 1770 roku wyekspediowany na Kamczatkę. Ucieczka z Kamczatki w dniu 12 maja 1771 roku na opanowanej przez niego rosyjskiej korwecie "Swięty Piotr i Pawel" wzdłuż wybrzeży Japonii i Chin do portugalskiego Makao, skąd następnie udał się do Francji, przyniosła Beniowskiemu światowy rozgłos is sławę ${ }^{19}$.

We Francji Maurycy Beniowski uzyskał 16 lipca 1772 roku od przebywających na emigracji marszałka konfederacji generalnej koronnej Michała Hieronima Krasińskiego, podkomorzego rożańskiego oraz marszałka generalnego litewskiego konfederacji Michała Jana Paca, starosty ziołowskiego, patent na stopień generała majora ${ }^{20}$. Wstąpił również do wojska francuskiego i został wysłany na Madagaskar w charakterze zarządcy tej wyspy. W 1776 roku odwolano go z tego stanowiska, ponieważ zamierzał $w$ porozumieniu $z$ miejscowymi plemionami

${ }^{15}$ I. Michalski, Schylek konfederacji barskiej, Wroclaw 1970, s. 125-126.

${ }^{16}$ Ibidem, s. 133.

${ }^{17}$ Ibidem, s. 163.

${ }^{18}$ M. A. Beniowski, Pamiętniki. Fragment konfederacki, oprac. L. Kukulski, S. Makowski, Warszawa 1967, s. 90-93, 108.

${ }^{19}$ A. Rocko, op.cit., s. 30; M. A. Beniowski, op.cit., s. 112-117.

${ }^{20}$ Ibidem, s. 111. 
przeksztalcić wyspę w niepodległe państwo. Wraca więc do Europy szukać sojuszników w celu ziszczenia swego projektu. W 1785 roku, korzystając z protekcji i finansowej pomocy członka angielskiego Towarzystwa Królewskiego, Johna Magellana oraz ze wsparcia amerykańskich kupców zorganizowal Beniowski wyprawę na Madagaskar, gdzie rozpoczął organizować własne państwo. Zginął w dniu 23 maja 1786 roku $z$ rąk francuskich żołnierzy $y^{21}$.

Nie mniej burzliwe były losy jednego z najbardziej znanych, obok Beniowskiego, konfederatów, Kazimierza Pułaskiego, starosty zezulnickiego i uczestnika Rady Wojennej konfederacji barskiej.

Pułaski należał do wąskiego grona wojskowych, którzy podczas prowadzonych działań militarnych wykazywali się dużym zmysłem taktycznym. Jak słusznie zauważył Stanisław Kwasieborski, „w tłumie pochlebców i zarozumialców, polityków o szerokich gębach a ciasnej mózgownicy, powiatowych despotów, intrygantów, a często nawet zdrajców, $w$ tłumie, który był tyle dzielnym zawsze w słowach, a tak skromnym w czynie" Pulaski był jednostką szczególnie wybitną ${ }^{22}$. Niestety, został uznany za jednego z głównych autorów planu porwania króla Stanisława Augusta i okrzyknięty „królobójcą”. Wobec powyższego, gdy zawiodły wszelkie nadzieje na zwycięstwo Barzan, 31 maja 1772 roku Pułaski opuścił Częstochowę i udał się na Śląsk, a następnie do Francji ${ }^{23}$.

Kazimierz Pułaski usiłował uzyskać za pośrednictwem swego brata Antoniego, starosty czereszeńskiego i Stanisława Lubomirskiego, marszałka wielkiego koronnego, zgodę carycy Katarzyny II i króla Stanisława Augusta na powrót do kraju. Przez pewien czas mieszkał w Nancy, w domu gen. Antoniego Karola du Houx hrabiego de Viomenil. Przywódcy konfederaccy nie zgodzili się na jego uczestnictwo w zjeździe w Landshut. Pominęli równieź Pułaskiego przy ustalaniu listy konfederatów ubiegających się o zapomogę rządu francuskiego. Od maja 1773 roku mieszkał w Dreźnie ${ }^{24}$. Wyrokiem Sejmu Rzeczypospolitej z 16 sierpnia 1773 roku Kazimierz Pułaski został uznany winnym planowanej zbrodni „królobójstwa”, pozbawiony majątku oraz skazany na śmierć przez ścięcie. Pułaski wziął udział w wojnie na Bałkanach po stronie Turcji, a następnie bezskutecznie zabiegał o przyjęcie kolejno do armii francuskiej i hiszpańskiej. W październiku 1775 roku został czasowo uwięziony za długi w Marsylii. Zaprzyjaźniony z Pułaskim dziejopis francuski Carloman Claude Rulhiere zapoznał go z przebywającym we Francji wysłannikiem Kongresu amerykańskiego Beniaminem Franklinem, który zarekomendował Pułaskiego w maju 1777 roku Jerzemu Waszyngtonowi. Na ziemi amerykańskiej stanął Kazimierz Pułaski 23 lipca 1777 roku i podjął energiczne działania w kierunku uzyskania patentu $w$ wojsku, w czym pomogła mu brawurowa osłona osoby Waszyngtona w bitwie z 11 września 1777 roku nad rzeką Brandyną.

${ }^{21}$ A. Roćko, op.cit., s. 30-31.

${ }^{22}$ S. Kwasieborski, op.cit., s. 108.

${ }^{23}$ Reszty pamiętników Macieja Rogowskiego, s. 25-26.

${ }^{24}$ W. Szczygielski, Pulaski Kazimierz, [w:] Polski Slownik Biograficzny [dalej PSB - R. Z.], t. 29/1, s. 390. Zdecydowanie więcej szczegółów na ten temat oraz w ogóle losów naszego bohatera znajdziemy w wymienionej już biografii Kazimierza Pułaskiego autorstwa Wladysława Konopczyńskiego. 
15 września 1777 roku Pułaski został mianowany generałem brygady i dowódcą całej kawalerii. Z funkcji tej złożył rezygnację po bitwie pod Haddofield ${ }^{25}$.

W dniu 28 marca 1778 roku Kongres amerykański potwierdził Pułaskiemu, na wniosek gen. Gatesa, rangę generała brygady i powołał go na dowódcę niezależnego korpusu, który miał prowadzić rozpoznanie i organizować zasadzki. Kazimierz Pułaski zastosował podczas szkolenia tej jednostki własne zasady musztry i szkolenia, które gen. Lee uznal „za najlepsze na świecie”. W legionie Pułaskiego służyl także inny konfederata barski, Jan Katkowski. Na swój wniosek został Pułaski przeniesiony w 1779 roku na front do południowej Karoliny, gdzie przyczynił się do odparcia oblężenia angielskiego pod Charleston i zmusił wraz z Lincolnem Anglików do wycofania się w kierunku Savannah. W bitwie pod Savannah został Kazimierz Pułaski ciężko rany. Zmarł 11 października 1779 roku, a w dniu 29 października 1779 roku Kongres amerykański podjął uchwałę o upamiętnieniu jego postaci pomnikiem. W 1867 roku popiersie Pułaskiego umieszczono na Kapitolu w Waszyngtonie wśród bohaterów narodowych Stanów Zjednoczonych Ameryki północnej. 13 maja 1793 roku Pułaski został rehabilitowany przez konfederację targowicką ${ }^{26}$

Przed zakończeniem działań wojennych konfederacji barskiej, w dniu 27 maja 1772 roku opuścił Cieszyn i udał się do Włoch regimentarz generalny sił zbrojnych konfederacji Joachim Karol Potocki, podczaszy litewski, a w trzy dni później uczynił to samo hetman wielki litewski Michał hr. Ogiński ${ }^{27}$. Joachim Potocki wyjechał z Cieszyna bez jakiegokolwiek oficjalnego pożegnania $\mathrm{z}$ wojskiem i zaleceń dla podkomendnych, udając się do Wenecji. Uczestniczył w zjeździe w Landshut. W dniu 1 lipca 1774 roku Sejm Rzeczypospolitej pozbawił Potockiego dowództwa nad regimentem koronnym. Do kraju Potocki wrócił w 1779 roku, aby w rok później zrezygnować z podczaszostwa litewskiego i calkowicie wycofać z życia publicznego ${ }^{28}$.

Na emigracji znaleźli się też obaj marszałkowie generalni, Michał Krasiński i Michał Pac. Michał Krasiński wziął udział w zjeżdzie w Landshut. W początkach 1773 roku Krasiński przebywał w Monachium, skąd przeniósł się w kwietniu tego roku do Szwajcarii. 10 kwietnia 1773 roku Michał Krasiński wraz z Michałem Pacem wydali $w$ Augsburgu protest przeciw projektom rozbiorowym, a 29 listopada 1773 roku przeciw uchwałom rozbiorowym Sejmu. Po trzech latach pobytu w Awinionie Krasiński wrócił do kraju i zamieszkal w Tuchowiczu, rezygnując z uczestnictwa w życiu politycznym ${ }^{29}$.

Największym autorytetem moralnym konfederatów na emigracji był bez wąqpienia Michał Jan Pac. W dniach od 27 maja do 26 lipca 1772 roku Pac byl internowany przez Austriaków w Żylinie. Następnie udał się do Braunau w Bawarii.

\footnotetext{
${ }^{25}$ Ib̉idem, s. 391-392.

${ }^{26}$ Ibidem, s. 392-393.

${ }^{27}$ J. Michalski, op.cit., s. 77-78.

${ }^{28}$ W. Szczygielski, Potocki Joachim Karal, [w:] PSB, t. 28/1, s. 55.

${ }^{29}$ Idem, Krasiniski Michal Hieronim, [w:] PSB, t. 15/1, s. 190.
} 
Uczestniczył w zjeździe w Landshut w dniach 11-14 grudnia 1772 roku i ogł wraz z Michałem Krasińskim manifest przeciwko rozbiorowi Rzeczypospoli Pac zamieszkał w Baden pod Zurychem, a następnie przeniósł się do Awinio. Nie skorzystał $z$ amnestii, która stwarzała szansę powrotu do kraju. Uzyskał s pendium Ludwika XVI w wysokości 24 tys. liwrów rocznie i zamieszkał na st w Lingolsheim pod Strasburgiem, gdzie zmarł w październiku $1787 \mathrm{roku}^{30}$.

Interesujące są także losy spiritus movens konfederacji barskiej, biskupa kam nieckiego Adama Stanisława Krasińskiego. Biskup Krasiński w czerwcu 1772 ro udał się na Śląsk do Koszęcina. 2 października 1772 roku został porwany z Łubiei nad Prosą przez Kozaków i odstawiony do Warszawy. 12 grudnia 1772 roku bisk Adam Krasiński podpisal zobowiązanie o lojalności względem króla i wypus czono go na wolność. Zamieszkał w Zegrzu w majątku swego kuzyna Kazimier Krasińskiego, oboźnego wielkiego koronnego. Odsunięto go od Senatu. W mar 1773 roku biskup napisał Projekt do naprawy praw i rzq̨du, w którym skrytyk wał system rządów saskich i postulował m.in. wprowadzenie tronu dziedziczneg Rady Nieustającej, zlikwidowania liberum veto oraz uwłaszczenie chłopów z kr lewszczyzn. Wypowiedział się także za aukcją wojska oraz postulował potrzel odbudowania polskiej dyplomacji ${ }^{31}$. Biskup Krasiński na kilkanaście lat wycof się z czynnego udziału w życiu politycznym, od 1780 do 1786 roku z przerw: mi pełnil funkcję przewodniczącego Sejmu sądowego, a w 1787 roku z rozkaz królewskiego zajmował się odbudową twierdzy Kamieniec Podolski. Do polityl powrócił podczas Sejmu Wielkiego. Był wówczas uznawany za główny filar oboz patriotycznego. W tym też okresie zbliżyl się w poglądach do Stanisława August i zostal 7 października 1789 roku przewodniczącym Deputacji do formy rzadt W nocy z 2 na 3 maja 1789 roku na zebraniu u Stanisława Małachowskiego jak pierwszy złożył swój podpis pod aktem słynnej Asekuracji.

Biskup Adam Krasiński był zdecydowanym oponentem rewolucji we Francj oraz neutralizował wzrastające wplywy masonerii. Ostrzegał również Stanisław: Augusta przed konsekwencjami przystąpienia do Targowicy i wojny domowej ora: zachęcał króla do walki o zdobycze Konstytucji 3 Maja. Biskup Krasiński odmówi złożenia przysięgi Katarzynie II. Na skutek tego został pozbawiony biskupstwa gdyż jego diecezja znalazła się w obrębie Rosji. W późniejszym okresie, już jakc sędziwy starzec, był zwolennikiem gen. Tadeusza Kościuszki i wspierał materialnie insurekcję, ale jednocześnie wypowiadał się negatywnie o polskich wadach narodowych ${ }^{32}$.

Na przeciwległym biegunie w stosunku do wyżej opisanych jednostek znaleźli się dwaj inni konfederaci, Szymon Marcin Kossakowski i Antoni Pulaski, syn starosty wareckiego Józefa Pułaskiego, twórcy związku wojskowego z 4 marca 1768 roku i pierwszego regimentarza generalnego wojska konfederackiego, jak również brat Kazimierza i Franciszka, starosty angustowskiego.

\footnotetext{
${ }^{90}$ Idem, Pac Michal Jan, [w:] PSB, t. 24/1, s. 733.

${ }^{31}$ Idem, Krasiński Adam Stanislaw, [w:] PSB, 15/1, s. 164.

${ }^{32}$ Ibidem, s. 164-165.
} 
Szymon Kossakowski, czyli „Litewski Pułaski - jeden z najdzielniejszych partyzantów", jak pisał o nim Wladysław Konopczyński, został internowany przez Austriaków w Preszowie i zmuszony do wyjazdu do Preszburga, skąd wymknął się do Wiednia. W końcu 1773 roku Szymon Kossakowski przybył do Paryża, gdzie projektował wznowienie działań zbrojnych konfederacji przy udziale ochotników serbskich, węgierskich, bulgarskich oraz austriackich dezerterów. Liczył również na pomoc ze strony Turcji i Francji, ale zawiódł się w swych rachubach. W tej sytuacji Kossakowski zlożył reces od konfederacji i pod koniec 1775 roku wrócił do kraju, aby już w roku następnym zostać wybranym na sejmiku kowieńskim posłem. Szymon Kossakowski uznał ugodę z Rosją za podstawę wszelkiej polityki. Zabiegał o względy carycy Katrzyny II i w uznaniu za swą postawę otrzymal Order św. Stanisława, a później także Order Orła Białego. W 1782 roku Szymon Kossakowski został posłem na Sejm Rzeczypospolitej, w latach 1786-1788 był członkiem Rady Nieustającej. Prorosyjski serwilizm zaprowadził go do carskiej armii, gdzie $w$ randze generała majora, później generała lejtnanta wziął udział w wojnie z Turkami na Bałkanach. Szymon Kossakowski był jednym z sygnatariuszy konfederacji targowickiej. $Z$ jego inicjatywy 25 czerwca 1792 roku protargowicką stała się Generalność litewska, a on sam ogłosil się hetmanem polnym litewskim ${ }^{33}$.

Szymon Kossakowski był jednym z najbardziej brutalnych przywódców Targowicy i stosował wobec jej oponentów represyjne metody. Kossakowski był także zwolennikiem połączenia Litwy z Rosją oraz domagał się odejścia $z$ wojska polskiego oficerów sympatyzujących z Konstytucją 3 Maja. Szymon Kossakowski był też orędownikiem kandydatury wielkiego księcia Konstantego na tron Rzeczypospolitej. Po śmierci Michala hr. Ogińskiego zostal hetmanem wielkim litewskim. W nocy z 23 na 24 kwietnia 1792 roku Kossakowski został aresztowany przez powstańców kościuszkowskich i osadzony w Arsenale. Dzień później Sąd Kryminalny skazal Kossakowskiego na śmierć przez powieszenie, co też nastąpiło natychmiast na Placu Ratuszowym w Wilnie ${ }^{34}$.

Także wspomniany Antoni Pułaski znalazł się w szeregach Targowiczan i był jej ostatnim urzędującym marszałkiem. Antoni Pułaski, jeden $z$ konsyliarzy konfederacji generalnej barskiej i pułkowników oraz dowódców chorągwi w pułku pod znakiem Krzyża św. został wzięty do niewoli 7 marca 1768 roku $22 \mathrm{~km}$ na północ od miejscowości Rzepińce przez rosyjskiego generała Izmaiłowa. Zesłano go do Kazania, gdzie zaciągnął się do armii rosyjskiej $i$ wzią udział w walkach $\mathrm{z}$ powstańcami Pugaczowa. W nagrodę za dzielną postawę $\mathrm{w}$ bitwach $\mathrm{z} 26$ lipca 1774 roku pod Carycynem i 4 wrzesnia 1774 roku pod Sokolnikowym Zawodem uzyskał zgodę na powrót do Warszawy, gdzie pojawił się w listopadzie 1775 roku i złożył reces od Baru. 5 stycznia 1776 roku Stanisław August nadał Pułaskiemu stopień pułkownika w wojsku litewskim. Antoni Pułaski pełnił także mandat posła z powiatu czerskiego i członka deputacji wyznaczonej do skontrolowania działalności Departamentu Wojskowego. Antoni Pułaski otrzymał patent na rotmistrza

\footnotetext{
${ }^{33}$ W. Konopczyński, Kossakowski Szymon Marcin, [w:] PSB, t. 14, s. 290-291.

${ }^{34}$ Ibidem, s. 292-293.
} 
w chorągwi kawalerii narodowej, ale zrezygnował z niego. W latach 1780-1781 był deputatem na Trybunał Koronny. 24 lutego 1791 roku otrzymał Order św. Sta. nisława. 9 lipca 1791 roku Antoni Pułaski, przeciwnik Konstytucji 3 Maja, stanął na czele protargowickiej lokalnej konfederacji wołyńskiej, uzyskując w nagrodę od Katarzyny II tabakierkę, a w styczniu 1793 roku Order św. Stanisława New. skiego. Pulaski pełnił od 1793 roku funkcję jednego z głównych doradców posła rosyjskiego w Warszawie, Sieversa. 26 marca 1793 roku obją stanowisko jednego z zastępców marszałka konfederacji targowickiej. Jako jeden $z$ nielicznych reprezentantów stanu szlacheckiego Antoni Pułaski starał się o uzyskanie zezwolenia Stanisława Augusta na złożenie hołdu i przysięgi nowej władczyni po II rozbiorze. W uznaniu za wierność interesom Rosji Katarzyna II mianowała go 11 maja 1793 roku generalnym inspektorem wojsk koronnych Rzeczypospolitej, a 14 maja tegoż roku otrzymał Order Orła Białego. Pozostając na żołdzie moskiewskim zabiegał u Katarzyny II o buławę wielką koronną. Tylko upadkowi powstania kościuszkowskiemu zawdzięcza to, że nie podzielił losu Szymona Kossakowskiego ${ }^{35}$.

Kolejnego konfederatę barskiego, Jacka Antoniego Puttkamera, sędziego ziemskiego rosieńskiego i członka Rady Wojennej przy Generalności, upadek ruchu zastał w Cieszynie. Wtedy to zdecydował się na emigrację i udał się do Drezna, a potem do Braunau w Szwajcarii i wziął udzial w zjeździe w Landshut. Puttkamer należał do grona konfederatów, którzy szukali pojednania z królem. W końcu 1776 roku wrócił do kraju i 16 października 1778 roku wszedł w skład sądu sejmowego. Był krytycznie ustosunkowany do Rady Nieustającej. 10 marca 1789 roku otrzymał Order św. Stanisława. W 1792 roku współtworzył wraz z Szymonem Kossakowskim konfederację targowicką. Był marszałkiem lokalnej konfederacji mińskiej. W maju 1797 roku w Mińsku car Paweł I nadał mu tytuł konsyliarza stanu i Order sw. Anny II kl. ${ }^{36}$

Interesujące są także pobarskie dzieje czeladnika rzeźnickiego Antoniego Jana Nepomucena Morawskiego, wyróżniającego się pod względem znajomości sztuki wojennej pułkownika konfederacji wielkopolskiej. Schwytany przez Kozaków mjr Iwana Drewicza w dwa dni po bitwie pod Widawą ( 23 czerwca $1771 \mathrm{r}$.), podczas której w znacznym stopniu przyczynil się do wygranej konfederatów, próbował uciec, ale ostatecznie powędrowal do Kazania, a potem do Tobolska. Z wygnania wrócił w 1774 roku i zaciągnął się do kawalerii narodowej, służył w partii wielkopolskiej, w chorągwi husarskiej tukasza Bińskiego, starosty sokolnickiego. W I brygadzie wielkopolskiej dosłużył się rangi kapitana. W dniu 27 maja 1794 roku Morawski zostal majorem milicji województwa łęczyckiego i komendantem pułku lekkiej jazdy milicji tegoż województwa. Antoni Morawski wziąl udzial w powstaniu kościuszkowskim, m.in. w obronie Warszawy i organizował pułk ułanów $w^{37}$. Jego dalsze dzieje są nieznane.

\footnotetext{
${ }^{35}$ W. Szczygielski, Pulaski Antoni, [w:] PSB, t. 29/1, s. 366-370.

${ }^{36}$ Idem, Puttkamer Jacek Antoni, [w:] PSB, t. 29/1, s. 474.

${ }^{37}$ Idem, Morawski Antoni Jan Nepomucen, [w:] PSB, t. 21/1, s. 707-708.
} 
Karierę wojskową na emigracji zrobił starosta łosicki i marszałek konfederacji bełskiej Józef Miączyński. W przegranej bitwie pod Lanckoroną (23 maja $1771 \mathrm{r}$.) Miączyński został ranny i wpadł $\mathrm{w}$ ręce rosyjskie. Pod naciskiem ambasadora Salderna złożył Miączyński 10 sierpnia 1771 roku pierwszy, a w trzy dni później drugi reces od konfederacji. Po wyjeździe do Cieszyna 9 lutego 1772 roku odwolał reces jako wymuszony, a w prawie miesiąc później udał się na Węgry. $10 \mathrm{maja}$ tegoż roku został aresztowany przez Austriaków, a 15 maja wrócił do Cieszyna, aby 30 maja wyjechać do Żyliny. Miączyński uczestniczył w zjeździe w Landshut. 11 lutego 1773 roku ponownie złożył reces od konfederacji i wrócił do kraju, gdzie objął funkcję figel - adiutanta królewskiego, a następnie funkcję dowódcy chorągwi pancernej w partii ukraińskiej i podolskiej. Józef Miączyński był również posłem na Sejm Rzeczypospolitej z ziemi czernihowskiej ${ }^{38}$.

W listopadzie 1779 roku Miączyński wyjechal do Paryża, gdzie roztrwonił majątek swej żony, Marie Francoise Chaboteaux i w 1783 roku został osadzony za długi w więzieniu, skąd zbiegł do Belgii. Na przełomie 1787/88 roku Miączyński splacił wierzycieli i wrócił do Francji. Tu też mógł cieszyć się z dzieła Konstytucji 3 Maja, jednak nie zdecydował się na powrót do Polski. Na wniosek gen. Dumouriez'a został 25 maja 1792 roku mianowany generałem brygady, a 4 czerwca 1792 roku otrzymał la decoration militaire. Zasłużył się we Francji formowaniem oddziałów strzelców konnych; został także komendantem twierdzy w Sedanie. Za spiskowanie przeciw Konwentowi Miączyńskiego zgilotynowano w dniu 22 maja $1793 \mathrm{roku}^{39}$.

Na emigracji znaleźli się głowni przywódcy konfederacji barskiej i wielu z nich nigdy już nie wróciło do kraju, a losy każdego $\mathrm{z}$ nich zasługują na odrębne omówienie. Decyzję o udaniu się na emigrację Barzanie podjęli pod wpływem perswazji Paca w trakcie trwania tajnej narady w nocy z 19 na 20 maja 1772 roku w Żylinie. Jako pierwsi wyjechali $z$ niej Ignacy Bohusz, sekretarz Generalności oraz Józef Miączyński ${ }^{40} .17$ maja 1772 roku powzięto $w$ Żylinie uchwalę przekazującą uprawnienia Generalności mniejszemu quorum, a w dniu 25 czerwca 1772 roku Pac i Michał Krasiński spisali manifest, w którym w nawiązaniu do przyjętej wcześniej uchwały zabezpieczyli „zachowanie cywilnej narodowej reprezentacyi" " Większość przywódców konfederackich znalazła się w Braunan w Bawarii.

Przedstawione powyżej losy niektórych z uczestników konfederacji barskiej nie wyczerpują w zupełności tematu, a wręcz przeciwnie, mogą stanowić jedynie wstęp do dalszych badań. Zupełnie odrębną grupę stanowią konfederaci, którzy powędrowali na Syberię. Zachowal się nawet w formie publikacji Regestr konfederatów barskich pulkownika. Thesby'ego de Belcoura $z 1774$ roku ${ }^{42}$, oficera francu-

${ }^{\text {sa }}$ Idem, Miquzyński Józef, [w:] PSB, t. 20/1, s. 560.

${ }^{39}$ Ibidem, s. 560-561.

${ }^{40}$ J. Michalski, op.cit., s. 84 .

${ }^{41}$ Ibidem, s. 91.

${ }^{42}$ Regestr zamieścił w swojej książce w ukladzie abecadłowym A. Kraushar, Konfederaci barscy na Syberyi (1774), Kraków 1895. Listę zawierającą 5445 nazwisk upowszechnil po powrocie $z$ wy- 
skiego i uczestnika konfederacji barskiej, który podzielil losy swych wspóltowarzyszy broni i został zesłany na Syberię po przegranej przez konfederatów bitwie z 10 grudnia 1769 roku w okolicach Różanej koło Piotrkowa ${ }^{43}$. Wśród jeńców barskich na Syberii znalazły się takie postaci, jak marszałkowie konfederacji krakowskiej Michał Czarnocki; sandomierskiej Piotr Potocki, wojewodzic wolyński; rożańskiej Antoni Albert Suffczyński, kasztelanic czerski; dobrzyńskiej Jakub Zieliński, chorąży nurski, czy wreszcie lubelskiej gen. Adam Szaniawski.

Taki choćby Stanisław Kostka Ortyński, pulkownik kozaków humańskich i komendant policji nadwornej Franciszka Salezego Potockiego odrzucił propozycję recesu od konfederacji, świadomie wybierając zesłanie do Kazania i później Tobolska, skąd wrócił na przełomie 1773/1774 roku ${ }^{44}$.

Losy konfederatów barskich na Syberii ukazuje wzruszający pamiętnik Karola Lubicz Chojeckiego, prostego szlachcica wziętego do niewoli po zajęciu Krakowa przez Moskali w 1768 roku, w której pozostał przez osiem lat, walcząc $z$ tęsknotą za ojczyzną i o biologiczne przetrwanie.

Dzieje Barzan, którzy znaleźli się na Syberii, są stosunkowo mało znane. We wstępie do pamiętnika Chojeckiego, Wojciech Turek szkicuje pokrótce tragedię jeńców polskich. Jak słusznie zauważa, zostali oni zdziesiątkowani w drodze na Syberię $\mathrm{i}$ „w domu niewoli", a większość z nich nigdy juź nie wróciła do Polskits.

W pierwszych dniach niewoli, w drodze do Kijowa i w samym mieście 600-osobowa grupa Karola Lubicz Chojeckiego stopniała o ponad połowę, a w grupie de Belcour'a z 257 konfederatów 97 zmarło w drodze do Kijowa, a kolejnych 64 już w samym mieście. Na Syberii znalazło się, co najmniej 9,8 tys. konfederatów, z czego 5,6 tys. $z$ nich zostało wcielonych do wojska rosyjskiego i wzięło udział w walkach $z$ powstańcami Jemielina Iwanowicza Pugaczowa, Kozaka dońskiego, podającego się za cudem ocalonego cara Piotra III. Konfederaci, których nie objęła amnestia z 1773 roku, znaleźli się po zakończeniu walk z Pugaczowem w pułku bachmuckim ( 1,1 tys. osób) i w garnizonach tobolskich (ponad 600 osób). Bunt konfederatów w Tobolsku z października 1774 roku skończył się zupełną klęską. 39-ciu konfederatom $z$ pułku bachmuckiego udało się uciec do Chin, a $120 \mathrm{z}$ Omska do Tatarów kirgiskich, skąd powrócilo z powrotem do Omska jedynie czterech $^{46}$. Kolejnych konfederatów objęly amnestie z 1781 i 1796 roku. Wielu $z$ nich przeszło na prawosławie, założyło rodziny i osiadło na stałe w Rosji. Jeszcze innych syberyjski generał gubernator Denis Czyczerin wysłał do Irkucka i kopalni srebra w Nerczyńskim Okręgu Górniczym lub osadzono na roli ${ }^{47}$. W 1855 roku

gnania w 1774 roku de Belcour daremnie zabiegając o wstawiennictwo głównych uczestników życia publicznego dIa nie objętych amnestią wspóitowarzyszy niedoli; por. K. L. Chojecki, op.cit., s. 10. De Belcour przedłożył także Stanisławowi Augustowi listy konfederatów z prośbą o uwolnienie oraz memoriał o warunkach życia i liczbie uwięzionych; patrz. A. Roćko, op.cit, s. 25.

${ }^{43}$ T. A. F de Belcour, op.cit., s. 14-15.

14 A. Roćko, op.cit., s. 22.

${ }^{45} \mathrm{~K}$. L. Chojecki, op.cit., s. 14.

${ }^{46}$ Ibidem, s. 14.

${ }^{47}$ A. Rocko, op.cit., s. 27-28. 
zyl jeszcze w gminie Tataurowskiej I. Kamieński, ponad 100-letni konfederat barski $z$ Wotynia ${ }^{48}$.

Wspomniany Karol Lubicz Chojecki po schwytaniu przez Rosjan został skierowany poprzez Kijów do Kazania, potem do Kunguru, Solikamska, a na początku 1771 roku znalazł się w Tobolsku. Latem 1771 roku przeniesiono go do Omska i wcielono do wojska, w 1772 roku służył w Korpusie Syberyjskim, kolejno w dragonii i piechocie, w latach 1773-74 uczestniczyl w thumieniu buntu Pugaczowa, a w 1776 roku znalazł się wraz ze swoją jednostką w okolicach Azowa, skąd zbiegł na Ukrainę i przez Dniepr wrócił do Polski ${ }^{49}$.

Konfederacja barska była jednym $z$ największych zrywów narodowych $w$ historii Polski i mimo jej mankamentów oraz nieudolności przywódców i ostatecznej klęski zbrojnej zapoczątkowała walkę z Moskwą o niepodległość kraju oraz jego odnowę moralną. Poza światem „wielkiej polityki” i gorszących konfliktów personalnych ukształtował się ruch, który stał się symbolem dla pokoleń walczących o odbudowanie Polski, zniszczonej i rozparcelowanej przez małość polskich elit, zaborczość sąsiadów i brak umiejętności odczytywania „znaków czasu”. Losy konfederatów barskich ukazują jedynie tragedię wyborów, jakich musieli dokonywać nasi przodkowie.

49. K. Chojecki, op.cit., s. 15.

A. Roćko, op.cit., s. 25-27. 